\title{
Uterine Corpus Carcinoma Pathologic TNM Finding v7
}

National Cancer Institute

\section{Source}

National Cancer Institute. Uterine Corpus Carcinoma Pathologic TNM Finding v7. NCI

Thesaurus. Code C89555.

A pathologic finding about one or more characteristics of uterine corpus carcinoma, following the rules of the TNM AJCC V7 classification system. TNM pathologic findings are based on clinical findings supplemented by histopathologic examination of one or more tissue specimens acquired during surgery. 